\title{
Racially Diverse US Young Adults' Experience of COVID-19-related anti-Asian Discrimination: Types and Emotional Reactions
}

Hyeouk Chris Hahm ( $\sim$ hahm@bu.edu )

Boston University School of Social Work https://orcid.org/0000-0001-6622-7628

Casey Xavier Hall

Northwestern University's Institute for Sexual Gender and Minority Health and Wellbeing

Kana Tsurudome Garcia

Boston University School of Social Work

Anna Cavallino

Boston University School of Social Work

Yoonsook Ha

Boston University School of Social Work

Yvette C. Cozier

Boston University School of Public Health

Cindy Liu

Brigham and Women's Hospital

\section{Research article}

Keywords: Discrimination, racism, anti-Asian discrimination, COVID-19, China Virus

Posted Date: April 3rd, 2021

DOl: https://doi.org/10.21203/rs.3.rs-380377/v1

License: (9) This work is licensed under a Creative Commons Attribution 4.0 International License.

Read Full License

Version of Record: A version of this preprint was published at BMC Public Health on August 18th, 2021. See the published version at https://doi.org/10.1186/s12889-021-11559-1. 


\section{Abstract}

Objectives: Little is known about both Asian and Asian American (A/AA) and non-Asian young adults' experiences and emotional reactions regarding COVID-19 anti-Asian discrimination. This is the first study to explore the nature and impact of COVID-19 anti-Asian discrimination through a racially diverse sample.

Design: This study uses open-ended qualitative free-text responses from Wave I of the COVID-19 Adult Resilience Experiences Study (CARES) data collected between March to September 2020. Thematic analysis was used to explore two open-ended questions: "Are there experiences we missed in the survey so far that you wish to describe?" and "What are your thoughts about the current social climate?" The data analysis for this study focused on 113 discrimination or racism-related comments.

Results: A total of 1,331 young adults completed an online survey of which 611 provided comments; a total of 95 racially diverse individuals (65.3\% non-Asians) contributed 113 COVID-19 anti-Asian discrimination or racism-related comments. Two overarching themes were: types of discrimination (societal, interpersonal, intrapersonal), and emotional reactions to discrimination (fear, anxiety/distress, hopeless/depression, and avoidance). Not only did both A/AA and non-Asian participants report witnessing or hearing reports of anti-Asian discrimination, but both groups reported experiencing negative emotional reactions to anti-Asian discrimination.

Conclusion: Anti-Asian discrimination in the face of COVID may be more widespread than initial reports indicate. Our finding suggests that anti-Asian discrimination is a societal illness that impacts all populations in the U.S. This calls for cross-racial coalitions and solidarity in the fight against discrimination and racism.

\section{Background}

The emergence of the coronavirus (COVID-19) in December of 2019 from Wuhan, China has led to a global health crisis. As of December 2020, the COVID-19 death toll has surpassed 1.51 million worldwide, with over 276,000 deaths within the U.S. The COVID-19 pandemic has threatened the well-being of individuals due to its global health and economic impact. Similar to other outbreaks throughout history [1], COVID-19 has resulted in the blaming of individuals on the basis of race/ethnicity and national origin. Initial research has documented increasing COVID-19-related discrimination in the U.S. against Asians and Asian Americans (A/AA), given the origin of the virus [2]. A growing number of $A / A A$ have experienced in-person and overt discrimination in the form of verbal and/or physical assault including racial slurs, wrongful workplace termination, or being stared at. A/AA communities have countered discrimination through campaigns such as \#IAmNotAVirus, however, these types of experiences may lead to the internalization of racist attitudes and stereotypes [3].

The most notable anti-Asian COVID-19-related discrimination has stemmed from the president of the U.S., referring to the virus as "the China virus" or "Kung Flu" [4]. The purposeful and persistent use of racist 
terminology, even after the World Health Organization (WHO) requested individuals refrain from using them, is highly stigmatizing. These public statements have been blamed for intensifying racism against A/AA.

Social media platforms such as Twitter, Facebook, and Instagram have further engaged in virtual displays of racism against A/AAs. Data gathered between November 1, 2019, to March 22, 2020 from two prominent online web platforms revealed significant increases in racial slurs such as "\#WuhanVirus," "\#Kung-Flu," "\#China kids stay home," and "\#Ching Chong." The term "Chink" was the most popular slur, increasing from about 1,250 twitter mentions to more than 3,500 mentions during March 2020 alone [2, 5].

While the negative health impacts of discrimination on A/AA are documented in the literature [6], the impacts of COVID-19-related anti-Asian racial discrimination on non-Asian communities has not been examined. The Harrell Model (2000) posits physical, psychological, social, functional, and spiritual consequences of discrimination [7]. In fact, this model and prior research also suggests that vicarious experiences of racism can lead to distress, anxiety, heightened sense of danger, and other psychological reactions irrespective of the racial identity of the indirect target of these experiences $[7,8]$. In other words, COVID-19 anti-Asian discrimination that is directly witnessed, viewed online, or relayed through stories, may have negative impacts on the mental health of both A/AA and non-Asian people. Since the COVID-19 pandemic, many non-Asian Americans have voiced their concerns after witnessing their friends, family members, or even strangers deal with anti-Asian discrimination.

A growing number of studies have begun to investigate the impact of discrimination on Asian American families [9], Asian American young adults [10], or Asians in Asian countries [11]. Studies have also highlighted the increasing impact of social media on this type of discrimination $[12,13]$. Very few studies have yet to provide empirical data documenting the impact of COVID-19-related discrimination on nonAsians in the U.S.

\section{The Current Study}

The current study seeks to examine qualitative descriptions of COVID-19 related discrimination experiences among a racially diverse sample of young adults in the U.S. from the COVID-19 Adult Resilience Experiences Study (CARES) [14]. Through thematic analysis of free-text comments in survey responses, this study examines descriptions of various discrimination experiences and participant reactions to discrimination. To our knowledge, this is the first study to investigate the impacts of COVID19 anti-Asian discrimination on a racially diverse sample, including A/AA and non-Asian young adults in the U.S.

\section{Methods}

\subsection{Data}


This study uses data from Wave I of the COVID-19-CARES [15], a longitudinal study examining the psychosocial experiences of individuals ages 18-30 years across three time points from 2020 to 2021. The purpose of CARES is to assess a range of COVID-19 related experiences, including discrimination, psychiatric symptoms, and physical and mental health functioning among young adults. Subjects were recruited through social media, email listservs, and word of mouth to complete a 30-minute online survey which included two open-ended qualitative response questions: 1) "Are there experiences we missed in the survey so far that you wish to describe?," and 2) "What are your thoughts about the current social climate?" All participants were either currently living in the U.S. or attended U.S.-based educational institutions. To ensure data quality, the online survey embedded various attention checks and human verification questions. Every 10th participant to enroll received a $\$ 25$ gift card. This study was reviewed and approved by the [Insert University] Institutional Review Board (IRB). The current analysis includes study participants who responded to open-ended qualitative response questions.

\section{Analysis}

Our analysis focused on free-text responses to open-ended questions and the terms racism and discrimination were used interchangeably because participants tended not to make specific distinctions. Qualitative analyses were conducted by three members of the research team $(\mathrm{HCH}, \mathrm{KG}, \mathrm{AC})$ who independently read and sorted the comments into four major themes: discrimination/racism, college relocation, political climate, and relationships. Given our goal to examine discrimination-or racism-related content, we restricted the analysis to discrimination-related comments only $(n=113)$, reported by 95 respondents. We organized and analyzed the free-text data into a matrix based system according to theme [16], following the five stages of thematic analysis-the Framework Methods [17]. First, each qualitative research team member read the data independently. Second, each member read the text, line by line, and coded the responses describing discrimination-related comments. Third, the team members worked together to develop an analytic framework. They compared individual codes and agreed on the standardized set of codes to be applied to all subsequent comments. Codes were then grouped into categories resulting in the development of a tree diagram. Fourth, this analytic framework was then applied to the rest of the responses, whereby a spreadsheet was used to generate a matrix. The data was then charted into the matrix by summarizing the categorized data from each transcript. Finally, team members identified the characteristics and differences within the data in order to discover theoretical concepts and map the connections between the categories. From this, the following themes were identified: types of discrimination, manifestations of discrimination (direct experience or vicarious), and reactions to discrimination (Figure 1). Reliability among the coders was maintained through a consensus approach of comparing codes across the same data by multiple members of the research team in order to resolve ambiguities. Resolution was achieved through the agreement of a standardized code that encompassed all three coders findings.

\section{Results}


Between April 13 and September 30, 2020, a total of 1,331 young adults completed the 30-minute Wave I CARES online survey. Of this, 611 participants provided a response for at least one of the two open-ended questions. Table 1 includes the 95 participants who reported discrimination and racism-related comments. Participants ranged in age from 18 to 30 years old (mean=24.5 years), were mostly female (85.3\%), and were racially diverse: $45.3 \%$ White, 34.7.\% Asian, 7.4\% Black, 4.2\% Hispanic/Latinx, 6.3\% mixed race, and $2.1 \%$ of another

race (including American Indian/Native American participants). One in five participants was foreign born $(20.0 \%)$ and $41.3 \%$ were first- or second-generation immigrants; $99 \%$ reported having at least attended some college, and $88.4 \%$ reported stable or extremely stable housing (88.4\%).

Figure 1 describes the conceptual model of qualitative data analysis. We further defined the types of discrimination reported into three socioecological categories: societal, interpersonal, and intrapersonal. Emotional reactions include fear, anxiety/distress, hopelessness/depression, and avoidance.

\section{Societal level ("Political Discrimination")}

Participants commented about witnessing COVID-19 related discrimination within social and political contexts through various platforms including the news, newspapers, and social media. Participants made remarks pertaining to how U.S. political leaders have reinforced racial discrimination against the Chinese through the COVID-19 crisis. Comments also referred to the fractured current political system, contentious foreign policy, belligerent trade negotiations with China, and the anti-immigrant policy justifying blame of China and A/AA for the cause and spread of COVID-19. This included the coining and repetition of culturally ethnocentric phrases such as "China flu."

\section{Interpersonal level ("Direct" vs "Vicarious" discrimination)}

We define the interpersonal level of discrimination as either direct or vicarious discrimination. First, direct discrimination has two manifestations: overt or blatant acts of prejudice (e.g., verbal or physical abuse, slurs, or threats); and covert or microaggressions, the unintentionally offensive acts of prejudice including subtle, derogatory slights, demeaning acts, or insults [18]. Second, vicarious discrimination was experienced both in-person and online. Participants reported being indirectly exposed to a blatant act of racism or discrimination targeted towards $A$ /AA such as witnessing or hearing about incidents of direct discrimination either, overt, or covert. Based on our data, it appears that vicarious discrimination was witnessed by participants of all races, as both A/AA and non-Asian participants reported vicarious forms of discrimination.

\section{Intrapersonal level ("Internalized discrimination")}

We classified internalized discrimination as discrimination at the intrapersonal level. Internalized racism was described as the acceptance of negative attitudes, beliefs, and stereotypes perpetuated by the society level and interpersonal level of discrimination [19]. 
Participant accounts of internalized racism frequently portrayed conflicting experiences of A/AA struggling with, accepting, and at times perpetuating anti-Asian stereotypes. A commonly reported example was the avoidance of A/AA businesses by those who were also A/AA who feared they may contract the virus through contact with other patrons. Participants reported feeling troubled that they were rejecting their own culture that they once embraced. This included feeling conflicted about their $A / A A$ backgrounds.

Table 2 indicates the four different types of anti-Asian discrimination based on societal, interpersonal, and intrapersonal levels and the emotional reactions from the discrimination reported by both $A / A A$ and non-Asians. Out of 113 comments, $57.5 \%(n=65)$ described the types of discrimination and $15.5 \%(n=18)$ described an emotional reaction to anti-Asian discrimination. A total of $5.3 \%(n=6)$ comments were related to anti-Black discrimination, but this theme was excluded since the scope of paper is anti-Asian discrimination.

Within the 113 free-text responses received from the survey, the $49.6 \%$ of discrimination-related comments referenced interpersonal discrimination. Common excerpts included racial slurs and negative stereotypes towards the A/AA community in the form of jokes and direct slander. Within the discrimination-related comments, 11 comments (16.9\%) were coded as covert microaggressions. Common themes within the microaggression responses included but were not limited to staring, avoidance by employees, and racial stereotyping. Numerous non-Chinese Asians also wrote that their nationality and race was questioned, despite not being Chinese, and felt that the questioning was both unnecessary and invasive. With those who did claim to be of Chinese descent, they found their identities to be negatively linked to the origin and spread of the virus.

Among the responses, vicarious discrimination (67.7\%) was more commonly reported than direct discrimination. Both $\mathrm{A} / \mathrm{AA}(\mathrm{n}=8,12.3 \%)$ and non-Asians $(\mathrm{n}=36,55.4 \%)$ reported witnessing or hearing reports of anti-Asian discrimination such as physical attacks, verbal attacks, or harassment against friends, family, and strangers who are or are assumed to be Chinese. In particular, participants noted a surge in online vicarious racial discrimination against A/AA, which were described as rampant, ignorant, blunt, politically divisive, and distorted.

\section{Emotional Reactions}

Table 2 indicates that out of 113 comments, $15.9 \%$ were about emotional reactions in relation to antiAsian discrimination. Two of the most common reactions were: fear and anxiety/distress. Due to the highly frequent reports of physical and verbal assaults heard on the media and reported by friends and family, A/AA reported that they feared leaving home even for routine tasks such as grocery shopping, for fear that they may be confronted with direct discrimination.

These emotional reactions to anti-Asian discrimination were also reported by non-Asian young adults. Although these respondents reported that they were not the likely target of anti-Asian racism or discrimination, their vicarious experiences resulted in a negative mental toll despite their non-Asian 
status. Non-Asian participants reported being afraid for their spouses, friends, or extended family members who are A/AA due to increasing anti-Asian racism. They also reported strong emotional reactions both for themselves and for those in their close family or social circles. The comments, heavily influenced by highly publicized political racism, were shocking and many participants reported feeling hopeless and exhausted about the inevitability of future encounters and frustrated by the lack of intervention toward the tense racial climate.

\section{Discussion}

The purpose of this study was to explore racism and discrimination narratives written by racially diverse U.S. young adults who participated in CARES [14] during the first six months of the COVID-19 pandemic in the U.S. To our knowledge, the data reported in this paper represent the first study to analyze free-text survey comments pertaining to anti-Asian discrimination during COVID-19. Among the comments received by 611 participants, 95 racially diverse individuals wrote comments on COVID-19 anti-Asian discrimination/racism.

Such data on research questionnaires provide a valuable opportunity to further understand the pressing issues among the participants, yet are often neglected as a data source [20].

The biggest contribution of our study is that we examined both A/AA and non-Asian's narratives regarding anti-Asian discrimination in the context of the COVID-19 pandemic. Our results show that both A/AA and non-Asian participants reported witnessing or hearing reports of anti-Asian discrimination. Moreover, both groups reported experiencing negative emotional reactions to anti-Asian discrimination. Thus, anti-Chinese discrimination in the face of COVID-19 may be more widespread and may have a greater negative societal impact than initially thought by affecting Chinese, non-Chinese Asian, and nonAsian populations in the U.S.

The thematic analysis of text comments focusing on racism/discrimination allowed the emergence of two themes: types and emotional reactions of discrimination. This study demonstrated that these multifaceted discrimination experiences are very salient given the social climate in the U.S. The intensity of interpersonal discrimination was widespread, evidenced by interpersonal discrimination reported in a variety of locations including on the street, on social media, in shopping malls, at school, and at work.

One of the most troubling aspects commented by participants was that anti-Asian discrimination was justified by institutional authority, referring to COVID-19 as "Wuhan Virus," "China Virus," and "Kung Flu." The closest modern analogue to the types of racism, fear, and sense of insecurity, as well as the pervasiveness and regular occurrence of anti-Asian discrimination related to COVID-19 may be the ethnocentric experiences reported by Arab and Muslim Americans post-9/11, 2001 [21]. The discrimination that Arabs and Muslims experience range from name-calling to workplace discrimination, physical violence, and murder. This kind of pervasive ethnocentric response to world events can have detrimental impacts on individuals and communities. Both A/AA and non-Asians expressed their 
concerns that this normalization of racism against A/AA can lead to increased racial violence and perpetualization of anti-Asian racism.

Of particular note was the generalization of discrimination to non-Chinese Asian people who were misidentified as Chinese. Non-Chinese Asians reported experiencing blatant racism and felt that it was unfair that all East Asians were treated as Chinese and became victims of racism. This may lead to resentment among the myriad of A/AA communities in the U.S., leaving the broader Asian minority group unprotected, isolated, marginalized, and further divided among themselves.

The description of reactions to anti-Asian discrimination during the COVID-19 pandemic should raise alarm. The most common emotional reaction to racial discrimination was intensified fear for either their own lives or their loved ones. The fear was beyond a degree of minor discomfort; it immobilized people from going outside their own homes. This degree of hypervigilance due to racist experiences may have detrimental impacts on the mental health of people who experience it $[22,23]$.

Though the context of the COVID-19 pandemic has arguably intensified anti-Asian discrimination, it is overlaying a foundation of persistent anti-Asian discrimination in the U.S. Asian Americans have been subject to various forms of social repression throughout U.S. history including the codification of antiAsian racism in U.S. law in the Chinese Exclusion Act of 1882 and the ever-present treatment of Asian Americans as "perpetual foreigners" resulting in a sense of "aliens in their own lands." The perpetuation of Asian-specific stereotypes indicate that Asians are often not being accepted as true Americans regardless of where they were born or how many years they have lived in the U.S. [24, 25]. These hostile social and structural environments are already challenging and create chronic stress, chronic illness, and psychological distress among A/AA [23]. Our study provides evidence that COVID-19 substantiated an intense explosion of various types of discrimination and the harmful emotional tolls of anti-Asian discrimination to both A/AA and non-Asians. Thus, elimination of anti-Asian discrimination will benefit those beyond the A/AA population, and we as a society must strive to achieve this goal.

\section{Limitations}

The study's limitations should be noted in the interpretation of the present study. Experiences were volunteered by participants in response to open-ended questions, however, such questions were not designed to elucidate detailed accounts. Future studies should employ more in-depth qualitative methods such as qualitative interviews to collect in-depth accounts of the social processes described in this analysis including potential coping mechanisms through which people address the harmful effects of anti-Asian discrimination.

\section{Conclusion}

Overall, these findings suggest that anti-Asian discrimination in the face of the COVID-19 pandemic is salient and impactful in both A/AA and non-Asian peoples' lives. The perpetuation of racism and ethnocentrism by national leaders and community members tap into pre-existing anti-Asian sentiment 
and pose detrimental psychological impacts on both A/AA and non-Asian people. Additional research is needed to understand the social processes involved in these event-driven increases in racism, the impact of racism on health, and the design of interventions for reducing their incidence and preventing their detrimental psychological impact.

\section{Declarations}

Funding: Support for this manuscript was provided through the National Science Foundation (NSF, 2027553) award (to H.C.H. and C.H. L), a Mary A. Tynan Faculty Fellowship and a NIMH K23 MH 107714$01 \mathrm{~A} 1$ award (to C.H.L.).

Conflicts of interest/Competing interests: None.

Ethics approval: Boston University Institutional Review Board (IRB). Informed consent was obtained from all participants. Each individual was required to consent online prior to proceeding with the online survey.

Consent for publication: All authors consented for publication

Availability of and material: Not applicable

Code availability: Not applicable

Authors' contributions: Hyeouk Chris Hahm is the PI of the CARES study who designed and conceived the study manuscript, analyzed qualitative data, and wrote the first draft of the paper. Casey Xavier Hall refined the qualitative modeling and wrote the introduction and discussion sections with the first authors. Kana Tsurudome Garcia and Anna Cavallino performed qualitative data analysis and assisted in the construction of the figures and tables. Yoonsook Ha organized and performed the data analysis. Yvette C. Cozier critically reviewed the theoretical modelling and provided editorial assistance. Cindy Liu is the coPI of the CARES project who aided in the critical review of the manuscript and provided editorial assistance.

\section{References}

1. White A. Historical linkages: epidemic threat, economic risk, and xenophobia - The Lancet. https://www.thelancet.com/journals/lancet/article/PIIS0140-6736(20)30737-6/fulltext. Accessed 7 Nov 2020.

2. Lee $S$, Waters SF. Asians and Asian Americans' experiences of racial discrimination during the COVID-19 pandemic: Impacts on health outcomes and the buffering role of social support. Stigma and Health. 2020. doi:10.1037/sah0000275.

3. Speight SL. Internalized Racism: One More Piece of the Puzzle. The Counseling Psychologist. 2007;35:126-34. 
4. Yam K. After Trump's Covid-19 diagnosis, anti-Asian tweets and conspiracies rose 85\%: report. NBC News. https://www.nbcnews.com/news/asian-america/after-trump-s-covid-19-diagnosis-anti-asiantweets-conspiracies-n1243441. Accessed 7 Nov 2020.

5. Schild L, Ling C, Blackburn J, Stringhini G, Zhang Y, Zannettou S. "Go eat a bat, Chang!": An Early Look on the Emergence of Sinophobic Behavior on Web Communities in the Face of COVID-19. arXiv:200404046 [cs]. 2020. http://arxiv.org/abs/2004.04046. Accessed 8 Nov 2020.

6. Hahm HC, Ozonoff A, Gaumond J, Sue S. Perceived discrimination and health outcomes a gender comparison among Asian-Americans nationwide. Womens Health Issues. 2010;20:350-8.

7. Harrell S. A Multidimensional Conceptualization of Racism-Related Stress: Implications for the WellBeing of People of Color. The American journal of orthopsychiatry. 2000;70:42-57.

8. Heard-Garris NJ, Cale M, Camaj L, Hamati MC, Dominguez TP. Transmitting Trauma: A systematic review of vicarious racism and child health. Social Science \& Medicine. 2018;199:230-40.

9. Cheah CSL, Wang C, Ren H, Zong X, Cho HS, Xue X. COVID-19 Racism and Mental Health in Chinese American Families. Pediatrics. 2020;146:e2020021816.

10. Chen AC-C, Szalacha LA, Menon U. Perceived discrimination and its associations with mental health and substance use among Asian American and Pacific Islander undergraduate and graduate students. J Am Coll Health. 2014;62:390-8.

11. Cao W, Fang Z, Hou G, Han M, Xu X, Dong J, et al. The psychological impact of the COVID-19 epidemic on college students in China. Psychiatry Research. 2020;287:112934.

12. Wen J, Aston J, Liu X, Ying T. Effects of misleading media coverage on public health crisis: a case of the 2019 novel coronavirus outbreak in China. Anatolia. 2020;31:331-6.

13. Litam SDA. "Take Your Kung-Flu Back to Wuhan": Counseling Asians, Asian Americans, and Pacific Islanders With Race-Based Trauma Related to COVID-19. TPC. 2020;10:144-56.

14. Liu CH, Stevens C, Conrad R, Hahm CH. Evidence for elevated psychiatric distress, poor sleep, quality of life concerns during the COVID-19 pandemic among U.S. young adults with suspected and reported psychiatric diagnoses. Psychiatry Research. 2020;:113345.

15. Liu CH, Zhang E, Wong GTF, Hyun S, Hahm HC. Factors associated with depression, anxiety, and PTSD symptomatology during the COVID-19 pandemic: Clinical implications for U.S. young adult mental health. Psychiatry Res. 2020;290:113172.

16. Gale NK, Heath G, Cameron E, Rashid S, Redwood S. Using the framework method for the analysis of qualitative data in multi-disciplinary health research. BMC Medical Research Methodology. 2013;13:117.

17. Furber $C$. Framework analysis: a method for analysing qualitative data. African Journal of Midwifery and Women's Health. 2010;4:97-100.

18. Sue DW, Lin Al, Torino GC, Capodilupo CM, Rivera DP. Racial microaggressions and difficult dialogues on race in the classroom. Cultural Diversity and Ethnic Minority Psychology. 2009;15:18390. 
19. Jones CP. Levels of racism: a theoretic framework and a gardener's tale. Am J Public Health. 2000;90:1212-5.

20. Pill R, Wood F, Renold E, Robling M, Edwards A, Clare W. Welsh women's comments about breast problems and the care given: A qualitative study in the community. European journal of cancer care. 2003;12:240-8.

21. Abu-Ras W, Abu-Bader SH. The Impact of the September 11, 2001, Attacks on the Well-Being of Arab Americans in New York City. Journal of Muslim Mental Health. 2008;3:217-39.

22. Williams DR. Stress and the Mental Health of Populations of Color: Advancing Our Understanding of Race-related Stressors. J Health Soc Behav. 2018;59:466-85.

23. Okazaki S. Impact of Racism on Ethnic Minority Mental Health. Perspect Psychol Sci. 2009;4:103-7.

24. Gee GC, Spencer MS, Chen J, Takeuchi D. A nationwide study of discrimination and chronic health conditions among Asian Americans. Am J Public Health. 2007;97:1275-82.

25. Yoo HC, Gee GC, Takeuchi D. Discrimination and health among Asian American immigrants: disentangling racial from language discrimination. Soc Sci Med. 2009;68:726-32.

26. Chen JA, Zhang E, Liu CH. Potential Impact of COVID-19-Related Racial Discrimination on the Health of Asian Americans. Am J Public Health. 2020;110:1624-7.

27. Social Stigma Associated with COVID-19. 2020. https://www.who.int/docs/defaultsource/coronaviruse/covid19-stigma-guide.pdf.

28. Croucher SM, Nguyen T, Rahmani D. Prejudice Toward Asian Americans in the Covid-19 Pandemic: The Effects of Social Media Use in the United States. Front Commun. 2020;5. doi:10.3389/fcomm.2020.00039.

29. Schmitt M, Branscombe N, Postmes T, Garcia A. The Consequences of Perceived Discrimination for Psychological Well-Being: A Meta-Analytic Review. Psychological bulletin. 2014;140.

\section{Tables}

Table 1: Sample Characteristics $(\mathrm{n}=95)$ 


\begin{tabular}{|c|c|c|}
\hline Characteristics & $\mathbf{N}$ & Mean (SD) or \% \\
\hline Age & 95 & $24.5(0.3)$ \\
\hline $\begin{array}{l}\text { Gender } \\
\text { Women } \\
\text { Man } \\
\text { Non-Binary (includes Transsexual) }\end{array}$ & $\begin{array}{r}81 \\
10 \\
4\end{array}$ & $\begin{array}{r}85.3 \\
10.5 \\
4.2\end{array}$ \\
\hline $\begin{array}{l}\text { Race } \\
\text { Asian or Asian American } \\
\text { Black or African American } \\
\text { Hispanic or Latinx } \\
\text { White, Caucasian, Anglo, European American } \\
\text { Multiracial } \\
\text { Other racial identity }\end{array}$ & $\begin{array}{r}33 \\
7 \\
4 \\
43 \\
6 \\
2\end{array}$ & $\begin{array}{r}34.7 \\
7.4 \\
4.2 \\
45.3 \\
6.3 \\
2.1\end{array}$ \\
\hline $\begin{array}{l}\text { Sexual Orientation } \\
\text { Straight/Heterosexual } \\
\text { Gay, Lesbian } \\
\text { Bisexual } \\
\text { Asexual } \\
\text { Questioning } \\
\text { Self-Identify (pan sexual, queer), I prefer not to answer }\end{array}$ & $\begin{array}{r}60 \\
8 \\
13 \\
4 \\
1 \\
9\end{array}$ & $\begin{array}{r}63.2 \\
8.4 \\
13.7 \\
4.2 \\
1.1 \\
9.5\end{array}$ \\
\hline $\begin{array}{l}\text { Born in US } \\
\text { Yes } \\
\text { No }\end{array}$ & $\begin{array}{l}76 \\
19\end{array}$ & $\begin{array}{l}80.0 \\
20.0\end{array}$ \\
\hline $\begin{array}{l}\text { First/Second Generation Immigrant } \\
\text { Yes } \\
\text { No }\end{array}$ & $\begin{array}{l}38 \\
54\end{array}$ & $\begin{array}{c}41.3 \\
58.7\end{array}$ \\
\hline $\begin{array}{l}\text { Education Level } \\
\text { High School graduate } \\
\text { Some college, vocational or technical school or associate college } \\
\text { College degree } \\
\text { Above college (Masters, some doctoral, doctoral) }\end{array}$ & $\begin{array}{r}1 \\
29 \\
33 \\
32\end{array}$ & $\begin{array}{r}1.1 \\
30.5 \\
34.7 \\
33.7\end{array}$ \\
\hline $\begin{array}{l}\text { Student Status } \\
\text { Student } \\
\text { Non-student }\end{array}$ & $\begin{array}{l}58 \\
37\end{array}$ & $\begin{array}{l}61.1 \\
38.9\end{array}$ \\
\hline $\begin{array}{l}\text { Current Job Status } \\
\text { Employed } \\
\text { Unemployed }\end{array}$ & $\begin{array}{l}61 \\
34 \\
\end{array}$ & $\begin{array}{l}64.2 \\
35.8\end{array}$ \\
\hline $\begin{array}{l}\text { Income Level } \\
\text { No income } \\
\text { Under } 25,000 \\
25,000-49,999 \\
50,000-74,999 \\
75,000-99,999 \\
100,000-124,999 \\
125,000+\end{array}$ & $\begin{array}{r}13 \\
46 \\
16 \\
13 \\
1 \\
3 \\
3\end{array}$ & $\begin{array}{r}13.7 \\
48.4 \\
16.8 \\
13.7 \\
1.05 \\
3.2 \\
3.2\end{array}$ \\
\hline $\begin{array}{l}\text { Married } \\
\text { Yes } \\
\text { No }\end{array}$ & $\begin{array}{l}13 \\
82\end{array}$ & $\begin{array}{l}13.7 \\
86.32\end{array}$ \\
\hline
\end{tabular}


Housing Stability

Not at all Stable

Slightly Stable

Moderately Stable

Stable

Extremely Stable

$2 \quad 2.1$

$2-2.1$

$\begin{array}{ll}7 & 7.4\end{array}$

$55 \quad 57.9$

$29 \quad 30.5$

Table 2: Summary of findings by construct with selected quotes 


\begin{tabular}{|c|c|c|c|}
\hline \multicolumn{4}{|c|}{ Types of Racism $(n=65)$} \\
\hline \multicolumn{4}{|c|}{ Societal Level: Political discrimination } \\
\hline Construct and Definition & $\begin{array}{l}\text { Proportion } \\
\text { of } \\
\text { comments } \\
\text { on types } \\
\text { of racism } \\
\mathrm{n}=65\end{array}$ & \begin{tabular}{|l} 
A/AA \\
vs non- \\
Asian
\end{tabular} & Selected Quotes \\
\hline \multirow{2}{*}{\begin{tabular}{|l|} 
Political discrimination \\
Participant identifies a \\
negative political climate \\
in correlation with \\
systemic racism and \\
racist commentary made \\
by political authorities.
\end{tabular}} & \multirow[t]{2}{*}{$\begin{array}{l}\mathrm{n}=5 \\
(7.7 \%)\end{array}$} & \multirow{2}{*}{$\begin{array}{l}\text { A/AA, } \\
\text { n=0 } \\
0 \% \\
\text { non- } \\
\text { Asian, } \\
\text { n=5, } \\
7.7 \%\end{array}$} & $\begin{array}{l}\text { Reported by non-Asian (White) } \\
\text { I'd ask how Trump referring to COVID-19 as the } \\
\text { "Wuhan Virus", 'Chinese Virus", and "Kung Flu" } \\
\text { impacts opinions. }\end{array}$ \\
\hline & & & $\begin{array}{l}\text { Reported by non-Asian (White) } \\
\text { "The current social climate is very tumultuous } \\
\text { with acts of racism from the police and political } \\
\text { racism against Chinese people about the virus. I } \\
\text { think it is important for these conversations to } \\
\text { happen because being passive is just allowing } \\
\text { these problems to continue to exist. People } \\
\text { need to understand what is okay and what is } \\
\text { not okay." }\end{array}$ \\
\hline \multicolumn{4}{|c|}{ Interpersonal Level: Direct and Vicarious } \\
\hline Construct and Definition & \multirow{2}{*}{$\begin{array}{l}\mathrm{n}=1 \\
(1.5 \%)\end{array}$} & \multirow[b]{2}{*}{$\begin{array}{l}\text { A/AA, } \\
\text { n=1 } \\
1.5 \% \\
\text { non- } \\
\text { Asian, } \\
\text { n=0 } \\
0.0 \%\end{array}$} & Selected Quotes \\
\hline $\begin{array}{l}\text { Direct: } \\
\text { Overt Discrimination: a } \\
\text { blatant act of prejudice } \\
\text { experienced by the } \\
\text { participant directly (ie: } \\
\text { verbal or physical } \\
\text { abuse) }\end{array}$ & & & $\begin{array}{l}\text { Reported by A/AA: } \\
\text { "Got called a few racial slurs while walking in } \\
\text { the streets because I am Chinese. They used } \\
\text { the word "chink" quite a bit. Not sure if this is } \\
\text { due to COVID or just generalized racism but I'm } \\
\text { sure COVID didn't help." }\end{array}$ \\
\hline $\begin{array}{l}\text { Direct: } \\
\text { Covert } \\
\text { microaggressions: } \\
\text { subtle, unintentionally } \\
\text { offensive acts of } \\
\text { prejudice experienced by } \\
\text { the participant }\end{array}$ & $\begin{array}{l}\mathrm{n}=11 \\
(16.9 \%)\end{array}$ & $\begin{array}{l}\text { A/AA, } \\
\text { n=10 } \\
15.4 \% \\
\text { non- } \\
\text { Asian, } \\
\text { n=1 } \\
1.5 \%\end{array}$ & $\begin{array}{l}\text { Reported by A/AA: } \\
\text { "I was at the mall with } 3 \text { other friends, we are } \\
\text { all Asian. This one kiosk worker did not } \\
\text { approach us about the product they were } \\
\text { selling, but when a white couple walked by and } \\
\text { they were offered the product. Being sick with } \\
\text { something other than COVID and having to } \\
\text { figure out how to avoid getting COVID while } \\
\text { getting necessary care is stressful. It is also } \\
\text { hard living with people who are not taking it } \\
\text { seriously." }\end{array}$ \\
\hline \multirow[t]{2}{*}{$\begin{array}{l}\text { Vicarious } \\
\text { In-person vicarious } \\
\text { discrimination: } \\
\text { a blatant act of prejudice } \\
\text { witnessed by the } \\
\text { participant that was not } \\
\text { personally experienced } \\
\text { by the participant }\end{array}$} & \multirow[t]{2}{*}{$\begin{array}{l}\mathrm{n}=35 \\
(53.8 \%)\end{array}$} & \multirow[t]{2}{*}{$\begin{array}{l}\text { A/AA, } \\
\text { n=4 } \\
6.2 \% \\
\text { non- } \\
\text { Asian, } \\
\text { n=31 } \\
47.7 \%\end{array}$} & $\begin{array}{l}\text { Reported by A/AA } \\
\text { "It was scary to hear about my acquaintance } \\
\text { getting screamed at and physically assaulted } \\
\text { (pushed) in the town where we grew up. I never } \\
\text { experienced significant discrimination growing } \\
\text { up so this seems so far out of the ordinary." }\end{array}$ \\
\hline & & & $\begin{array}{l}\text { Reported by non-Asian (Black): } \\
\text { “When I was on public transportation, I } \\
\text { witnessed verbal abuse to someone I assumed } \\
\text { was of Asian descent - an older male who was } \\
\text { verbally assaulted by a young woman who was } \\
\text { also a person of color. }\end{array}$ \\
\hline
\end{tabular}




\begin{tabular}{|c|c|c|c|}
\hline & & & $\begin{array}{l}\text { Reported by non-Asian (White) } \\
\text { "I have a few younger cousins that are Asian } \\
\text { American, as well as my partner who is } \\
\text { Cuban/Cambodian, and they have all received } \\
\text { extreme criticism for their races and have been } \\
\text { verbally or physically assaulted because of their } \\
\text { heritage. My youngest cousins are } 2 \text { and } 5 \\
\text { years old and have been kicked out of their } \\
\text { preschool because of their race." }\end{array}$ \\
\hline $\begin{array}{l}\text { Vicarious: } \\
\text { Online vicarious } \\
\text { discrimination: } \\
\text { participant recalls } \\
\text { prejudicial comments } \\
\text { made against Asian } \\
\text { Americans on social } \\
\text { media platforms }\end{array}$ & $\begin{array}{l}n=9 \\
(13.8 \%)\end{array}$ & $\begin{array}{l}\text { A/AA, } \\
\text { n=4, } \\
6.2 \% \\
\text { non- } \\
\text { Asian, } \\
\text { n=5, } \\
7.7 \%\end{array}$ & $\begin{array}{l}\text { Reported by A/AA (Total number 4) } \\
\text { "I think there's a lot of xenophobia on social } \\
\text { media where racism is rampant. While I } \\
\text { understand social media users, as a whole, do } \\
\text { not have a super high education attainment, but } \\
\text { the ignorance and blunt racism still strike me." } \\
\text { Reported by non-Asian (White) } \\
\text { "Admittedly, it has been frustrating to see and } \\
\text { hear such incongruous "news" headlines and } \\
\text { rhetoric surrounding this virus. There is an } \\
\text { exorbitant amount of information that has been } \\
\text { so clouded and distorted by political divide, } \\
\text { international relations, and social commentary } \\
\text { that I cannot form any resident theory about the } \\
\text { ACTUAL state of things in the world, our } \\
\text { country, my state, or my county. Such distortion } \\
\text { and divide in place, the entire situation has only } \\
\text { been made more stressful and contentious, } \\
\text { which has made it personally more difficult to } \\
\text { deal with this unfolding situation." }\end{array}$ \\
\hline \multicolumn{4}{|c|}{ Intrapersonal Level: Internalized Discrimination } \\
\hline Construct and Definition & & & Selected Quotes \\
\hline $\begin{array}{l}\text { Internalized } \\
\text { discrimination: } \\
\text { People of colors' } \\
\text { internalized racism often } \\
\text { leads to great conflict } \\
\text { among and between } \\
\text { them as other concepts of } \\
\text { power-such as ethnicity, } \\
\text { culture, nationality and } \\
\text { class-are collapsed in } \\
\text { misunderstanding }\end{array}$ & $\begin{array}{l}n=4 \\
(6.2 \%)\end{array}$ & $\begin{array}{l}\text { A/AA, } \\
\text { n=4, } \\
6.2 \% \\
\text { non- } \\
\text { Asian, } \\
n=0, \\
0 \%\end{array}$ & $\begin{array}{l}\text { Reported by A/AA (Total number 4): } \\
\text { "I personally would never call or support those } \\
\text { who call COVID-19 the Chinese virus, but the } \\
\text { source of the virus is important given where we } \\
\text { live and how the world is built upon supremacy } \\
\text { and racism. However, thinking about how my } \\
\text { people might lose their loved ones because one } \\
\text { of my fellow Asians decided to eat a bat or } \\
\text { pangolin is uneasy to me and gives me a } \\
\text { considerable amount of regret and stress. As a } \\
\text { person who calls both countries home, I'm } \\
\text { conflicted by the voices I hear every day. China } \\
\text { is the place that gave me my childhood and my } \\
\text { parents, yet it also allegedly spread the virus } \\
\text { and concealed information from the world. On } \\
\text { the other side is where I consider my home, and } \\
\text { it's currently being invaded." }\end{array}$ \\
\hline \multicolumn{4}{|c|}{ Emotional Reaction from Racism $(n=18)$} \\
\hline Fear & $\begin{array}{l}\mathrm{n}=8 \\
(44.4 \%)\end{array}$ & $\begin{array}{l}\text { A/AA, } \\
\text { n=6, } \\
33.3 \% \\
\text { non- } \\
\text { Asian, } \\
\text { n=2, } \\
11.1 \%\end{array}$ & $\begin{array}{l}\text { Reported by A/AA } \\
\text { "I haven't faced discrimination, but I also } \\
\text { haven't left the house closed to for } 4 \text { weeks....In } \\
\text { fact, I fear leaving the house because I have } \\
\text { heard reports of multiple attacks in and around } \\
\text { my neighborhood." }\end{array}$ \\
\hline
\end{tabular}




\begin{tabular}{|c|c|c|c|}
\hline & & & $\begin{array}{l}\text { Reported by non-Asian (White) } \\
\text { "General fear and anger my Asian and Asian- } \\
\text { American friends have that live in NYC, due to } \\
\text { reports of assaults and experiencing verbal } \\
\text { assault themselves.” }\end{array}$ \\
\hline Anxiety/Distress & $\begin{array}{l}\mathrm{n}=5 \\
(27.8 \%)\end{array}$ & \begin{tabular}{|l|} 
A/AA, \\
n=2, \\
$11.1 \%$ \\
non- \\
Asian, \\
n=3, \\
$16.7 \%$
\end{tabular} & \begin{tabular}{|l|} 
Report from A/AA \\
"For me personally, I have a heightened sense \\
of anxiety when I go out. I feel like I'm almost \\
hyper-aware of non-Asians around me because \\
I'm afraid someone is going to lash out at me \\
because of my ethnicity. No one has verbally or \\
physically attacked me yet but I've seen so many \\
stories and videos of others being attacked. It \\
scares me." \\
Report from non-Asian (White) \\
My partner, who is Chinese, has experienced a \\
higher level of anxiety, and I have experienced \\
a higher level of anxiety because of their \\
anxiety.
\end{tabular} \\
\hline Hopelessness/Depression & $\begin{array}{l}\mathrm{n}=4 \\
(22.2 \%)\end{array}$ & \begin{tabular}{|l|} 
A/AA, \\
n=1, \\
$5.6 \%$ \\
non- \\
Asians, \\
n=3, \\
$16.7 \%$
\end{tabular} & \begin{tabular}{|l|} 
Report from A/AA \\
"Despite not being personally assaulted \\
verbally/physically due to my race, those \\
comments, videos or news articles online (both \\
within China and outside China) made me feel \\
depressed from time to time". \\
\\
Report from non-Asian \\
"It is exhausting and almost makes me feel \\
hopeless. Even though racism is being exposed \\
in institutions, public figures, and authority, \\
there is denial and resistance to reform them \\
which makes me feel distressed about it." \\
\end{tabular} \\
\hline Avoidance & $\begin{array}{l}\mathrm{n}=1 \\
(5.6 \%)\end{array}$ & \begin{tabular}{|l|} 
A/AA, \\
n=1, \\
$5.6 \%$ \\
non- \\
Asians, \\
n=0, \\
$0 \%$
\end{tabular} & $\begin{array}{l}\text { Report from A/AA (Total number 1) } \\
\text { "I have also adjusted my lifestyle (going out in } \\
\text { public less or going with my white husband) to } \\
\text { avoid discrimination. I stayed home from work } \\
\text { one day because my asthma was acting up and I } \\
\text { didn't want to be seen coughing or showing any } \\
\text { symptoms of illness because I am the only Asian } \\
\text { staff member at my workplace of 100." }\end{array}$ \\
\hline
\end{tabular}

\section{Figures}




\section{Types of COVID-19 Anti-Asian discrimination}
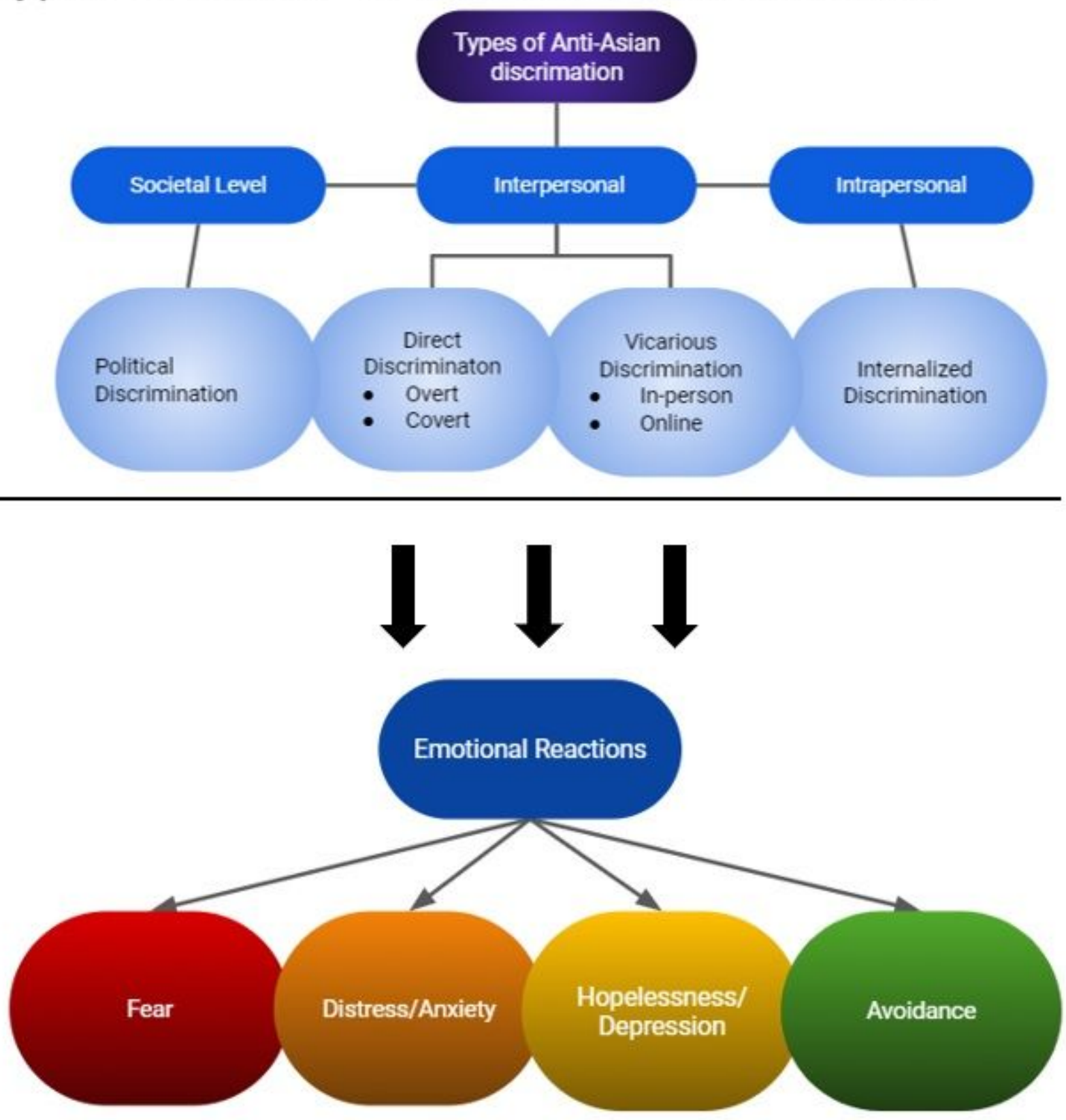

Figure 1

Conceptualizing Types of Discrimination and Emotional Reactions $(n=113)$

\section{Supplementary Files}

This is a list of supplementary files associated with this preprint. Click to download.

- CARESWave1Survey.pdf 